\title{
Edukacja kaszubska: rzecz o tym, jak praktyka edukacyjna „zaczepiła i ugruntowała” myślenie pedagogiczne. Przyczynek do namysłu nad teorią praktyki
}

Streszczenie: Artykuł charakteryzuje fragment praktyki społecznej, w ramach której społeczność kaszubska w Polsce Ludowej i w czasach przełomu transformacyjnego podejmowała działania zmierzające do ochrony praw do zachowania języka i kultury, pokoleniowej transmisji kultury, a w szczególności dopominała się o prawo do edukacji kaszubskiej w szkole. Artykuł opisuje też wybrane aspekty idei społecznej i edukacyjnej, jaka rodziła się w publicznej przestrzeni kaszubskiej, a w końcowej części charakteryzuje teorię edukacji regionalnej Kazimierza Kossak-Główczewskiego.

Słowa kluczowe: edukacja kaszubska, edukacja regionalna, metodyczna teoria edukacji regionalnej, pedagogiczna teoria edukacji regionalnej

\section{Wprowadzenie}

Już w 1945 roku władze PRL-u rozpoczęły wobec Pomorza i Kaszub działania w ramach tzw. polityki narodowościowej. Jej celem miało być wytworzenie spójnego kulturowo społeczeństwa, które pozbawione miało być wszelkich wewnętrznych różnic kulturowych. Chodziło więc o Nowe Społeczeństwo i Nowego Człowieka, który byłby nie tylko wyjałowiony z tego, co stanowiło o jego wyjątkowości, ale dodatkowo miał być wysycany świadomością socjalistyczną. Nadrzędną rolę przyjęła władza, która za pomocą swych wiernych instytucji - szkoły i partii - chciała konsolidować starą i nową ludność Pomorza i Kaszub i chciała wytworzyć Prawdziwego Polaka.

W nowej rzeczywistości nie było więc miejsca dla kaszubskiej odrębności kulturowej, tak jak nie było miejsca na inne mniejsze kultury w państwie. Jednak wbrew logice państwa Kaszubi podjęli starania o zachowanie kultury 
kaszubskiej i o edukację języka kaszubskiego, i z uporem domagali się prawa do ochrony i rozwijania swej odrębności kulturowej, w tym prawa do ochrony języka.

Celem tej pracy jest opisanie „fragmentu” zmagań o edukację kaszubską (w czasach przesilenia lat 80 . XX wieku do przełomu transformacyjnego włącznie), jaką podjęli Kaszubi, i zrekonstruowanie myślenia społeczno-edukacyjnego, które „pojawiło się” w kaszubskiej przestrzeni publicznej. I dalej: teorii edukacji regionalnej zrekonstruowanej przez Kazimierza Kossak-Główczewskiego na fundamencie doświadczeń płynących z działań społeczno-edukacyjnych i obecnego w kaszubskiej przestrzeni publicznej myślenia. Istotną częścią tej pracy jest próba rozpoznania i zrozumienia metodologicznej „właściwości” tworzonej edukacji kaszubskiej, a następnie jej pedagogicznej teorii, w postaci teorii edukacji regionalnej.

\section{O edukację kaszubską...}

O ile rok 1945 należy uznać za zamknięcie epoki wielokulturowości na Pomorzu i Kaszubach ${ }^{1}$, to lata 80. ubiegłego stulecia trzeba uznać za początek powrotu do idei wielokulturowości przez upomnienie się o szeroko rozumianą edukację pomorsko-kaszubską, a później o edukację kaszubską. Edukacja regionalna, w pierwszej swej wersji występująca jako regionalizacja treści nauczania, była niczym innym jak publicznym artykułowaniem roszczeń o wartości wnoszone właśnie przez kultury etniczne w poczet kultury ogólnopolskiej, gdyż w interesie „narodu polskiego” nie mogła/ nie może leżeć „uniformizacja społeczna”.

W latach 80. Kaszubi zaczęli dopominać się praw do $\left.\mathrm{do}^{3}: 1\right)$ zachowania wiedzy o kulturze kaszubskiej („o spuściźnie przodków”); 2) zachowania osobi-

1 M. Latoszek: Pomorze: zagadnienia etniczno-regionalne, Gdańsk 1996, Gdańskie Towarzystwo Naukowe, Akademia Medyczna w Gdańsku, s. 186; M. Latoszek: Pomorze: odkrywanie tożsamości w procesie długiego trwania. W: W. Świątkiewicz (red.): Regiony i regionalizmy w Polsce Współczesnej. Katowice 1998, UŚ, Śląskie Towarzystwo Socjologiczne, s. 69; C. Obracht-Prondzyński: Kaszubi: między dyskryminacją a regionalna podmiotowością. Gdańsk 2002, Wydawnictwo Instytutu Kaszubskiego, s. 157.

2 Por. O. Sochacki: Obraz Kaszubów w opinii publicznej. „Pomerania. Miesięcznik społeczno-kulturalny" 1987, nr 10, s. 3.

3 Por. F. Szczęsny: Kurs na młodzież. „Pomerania. Zarząd Główny Zrzeszenia Kaszubsko-Pomorskiego" 1980, nr 1 (96), s. 3. 
stych doświadczeń biograficznych Kaszubów; 3) zainteresowania młodzieży wiedzą o kulturze kaszubskiej, tj. szczegółową wiedzą o regionie; 4) ochrony dzieci, młodzieży i dorosłych przed upokorzeniami i zatraceniem kultury przez edukację formalną. Rozpoczęła się zatem żmudna batalia o wprowadzanie treści regionalnych do szkoły. Wydaje się, że Kaszubi reprezentowani przez Zrzeszenie Kaszubsko-Pomorskie (ZK-P) utwierdzili się w przekonaniu, że ich prawo do zachowania kultury i edukacji kaszubskiej (w tym języka) wynika z praw i zasad demokracji. Co prawda żadna demokracja nie gwarantowała i nie zagwarantuje Kaszubom wprost prawa do edukacji języka i kultury kaszubskiej, ale w jej idei zawiera się uznanie wolności do zachowania własnego dziedzictwa (a edukacja jest przecież metodą tego zachowania) ${ }^{4}$.

Już w grudniu 1980 roku Walny Zjazd Delegatów (WZD) ZK-P „upomniał się o edukację regionalną w szkole”, szczególnie ważkie dla dalszych działań okazały się dwa postulaty: 1) podjęcia badań socjologicznych nad stanem kultury na Kaszubach i Pomorzu; 2) zwiększenia możliwości wydawniczych w regionie, w celu popularyzacji dzieł z zakresu historii literatury kaszubskiej, i zwiększenia dostępności dzieł klasycznych i współczesnych ${ }^{5}$.

Początkowo w regionalizacji programów nauczania dopatrywano się szansy zapobiegania unifikacji kulturowej. Kontakt z wartościami regionalnymi czyli z tym, co swojskie i konkretne - kształtować miał postawy patriotyczne

4 I. Trojanowska: Wypowiedź w ramach Zjazdu. „Pomerania. Zarząd Główny Zrzeszenia Kaszubsko-Pomorskiego" 1981, nr 2 (109), s. 16; L. Bądkowski: My, literaci, żyjemy w środku narodu. „Pomerania. Zarząd Główny Zrzeszenia Kaszubsko-Pomorskiego" 1981, nr 3 (110), s. 1-2; Z. Talewski: Do kolegi Lecha Badkowskiego słów kilka. „Pomerania. Zarząd Główny Zrzeszenia Kaszubsko-Pomorskiego” 1981, nr 8 (115). Por. także: A. Kożyczkowska: „Aktywne uczestnictwo” jako zasada obywatelskości $i$ warunek demokratyzacji życia w regionie i państwie. Casus kaszubsko-pomorskiego ruchu regionalnego. Maszynopis złożony do druku. Trzeba jednak wyraźnie podkreślić, że lata 80. XX wieku to także czas sporu o kształt ruchu kaszubskiego, a właściwie o jego wymiar polityczny. Obok nurtu demokratyczno-politycznego, którego osią były kwestie kultury jako polityki z wszelkimi tego konsekwencjami i roszczeniami, obecny był nurt zachowawczy, odcinający się od polityki, „bezpieczny i bliższy”, którego sens koncentrował się na w dużej mierze na kulturalnej działalności wobec/ dla środowiska kaszubskiego.

5 Uchwała Walnego Zjazdu Delegatów Zrzeszenia Kaszubsko-Pomorskiego. Gdańsk, 14 grudzień $1980 r$. „Pomerania. Zarząd Główny Zrzeszenia Kaszubsko-Pomorskiego” 1981, nr 2 (109), s. 6. 
narodu i społeczności regionalnej. Jednakże Kaszubi chcieli nauczanie treści regionalnych ujmować nie tylko jako kształcenie, ale także jako wychowanie regionalne ${ }^{6}$. Trzeba też wyakcentować, że edukacja kaszubska już w swej wczesnej formie, jako regionalizacja programów nauczania, zmieniała rangę języka kaszubskiego: przestawał to być tylko „preparat do badań językowych”. Wprowadzenie języka kaszubskiego do szkoły oznaczało dla Kaszubów (i nie tylko), że kaszubski to „mowa żywa, używana praktycznie, rozwijająca się i zmieniająca". To już nie była tylko mowa/ język kilku literatów piszących po kaszubsku. „Kaszubski w szkole” stopniowo zyskiwał rangę tego, co atrakcyjne ${ }^{7}$, przez co mowa kaszubska przestała być „reliktem muzealnym”.

W kaszubskiej przestrzeni publicznej podjęto społeczno-kulturowy namysł nad edukacją, w którym niestety głosu nie zabrali pedagodzy. Uznano, że edukacja jest fundamentalną sprawą każdej społeczności i metodą zachowania dziedzictwa kulturowego regionu. Edukacja potrzebuje jednak „poznania” teraźniejszego życia regionu, jego przeszłości i rozpoznania oraz zrozumienia przeobrażeń, jakie w nim zaszły i zachodzą. „Uświadomienie sobie własnej tożsamości, w znaczeniu etnicznym, nie jest cechą daną człowiekowi w sposób naturalny" - pisał Jerzy Samp. Sposobem osiągnięcia tej świadomości jest potrzeba „aktywnego uczestnictwa w tym, co da się najkrócej określić mianem współudziału w akcie tworzenia nowej karty dziejów [...] owej »małej ojczyzny«" młodym to, co uznała za wartość najwyższą dla siebie samej, i to co określone zostanie jako wartość godna kontynuacji. Edukacja zapewni ciągłość ruchu

6 Por. J. Samp: Na których czekamy. „Pomerania. Miesięcznik społeczno-kulturalny” 1983, nr 5 (121), s. 9-10. H. Galus: Szkoła i region. „Pomerania. Miesięcznik społeczno-kulturalny" 1986, nr 5 (157), s. 5.

7 Wypowiedź Małgorzaty Czermińskiej: I. Trojanowska, M. Czermińską: Pisarze o nauczaniu w szkole. „Pomerania. Zarząd Główny Zrzeszenia Kaszubsko-Pomorskiego" 1981, nr 8 (115), s. 18-19.

8 J. Samp: Na których czekamy. „Pomerania. Miesięcznik społeczno-kulturalny” 1983, nr 5 (121), s. 10. Por. także: Wypowiedź Jerzego Tredera: E. Szcześniak, E. Breza i J. Treder: Wszystkie barwy słów. „Pomerania. Miesięcznik społeczno-kulturalny” 1983, nr 6 (122), s. 3. J. Samp: Zanim staniesz się niemy w mowie ojców. „Pomerania. Miesięcznik społeczno-kulturalny" 1984, nr 7 (135). J. Samp: Zanim staniesz się niemy w mowie ojców (dokończenie). „Pomerania. Miesięcznik społeczno-kulturalny” 1984, nr 8 (136)

9 J. Samp: Na których czekamy. „Pomerania. Miesięcznik społeczno-kulturalny” 1983, nr 5 (121), s. 10. 
regionalnego, a więc popularyzację idei, której jednak nowe pokolenie nada nową formę i nową jakość. Dla edukacji regionalnej ważne są trzy kwestie: 1) podnoszenie i utrwalanie rangi wartości kulturowych regionu; 2) dostęp do wiedzy o regionie i źródeł, wytworów kulturowych; 3) rozpoznanie tego, na ile i jakie treści regionalne są atrakcyjne dla młodego pokolenia ${ }^{10}$.

\section{Pierwsze działania na rzecz stworzenia podstaw edukacji regionalnej: regionalizacja programów nauczania}

Pierwsze próby stworzenia programu dla regionalizacji nauczania w zakresie kaszubszczyzny pojawiły się już w 1981 roku. Komisja Oświaty przy Zarządzie Głównym Zrzeszenia Kaszubsko-Pomorskiego (ZG ZK-P), pod przewodnictwem m.in. Edwarda Brezy i Henryka Galusa, zajęła się przede wszystkim problemem regionalizacji nauczania. Pierwszym realnym wówczas zadaniem - jak napisał Jerzy Treder - było opracowanie koncepcji poszerzających obowiązujące programy o treści regionalne. Istotne były wówczas odpowiedzi na dwa pytania: 1) czy treści regionalne - problematyka kaszubsko-pomorska - powinna być realizowana w ramach istniejących przedmiotów, czy też osobno? A jeśli osobno, to skąd „wygospodarować” godziny dla zajęć?; 2) czy i w jakim zakresie włączyć w program naukę pisania i czytania w języku kaszubskim? ${ }^{11}$

Efektem pracy Komisji Oświaty przy ZG ZK-P i zaangażowanych nauczycieli było przygotowanie programów szkolnych. Debata nad nimi odbyła się w październiku 1981 roku ${ }^{12}$. Na spotkanie przygotowano broszurę, która zawierała programy nauczania początkowego, historii i wychowania obywatelskiego, geografii, wychowania muzycznego, języka polskiego i wychowania regionalnego ${ }^{13}$. Stan wojenny wstrzymał jednak działania w zakresie

10 J. Samp: Na których czekamy. „Pomerania. Miesięcznik społeczno-kulturalny” 1983, nr 5 (121), s. 8-9.

11 J. Treder: Niektóre inicjatywy w dziedzinie edukacji regionalnej na Kaszubach. W: K. Kossak-Główczewski: Edukacja regionalna mniejszości narodowych $i$ etnicznych. Gdańsk 1999, UG, s. 27.

12 Materiały do dyskusji na temat regionalizacji nauczania. XI Spotkania Twórców Literatury Kaszubsko-Pomorskiej, Wdzydze, 9-10 X 1981 r.

13 J. Treder: Niektóre inicjatywy w dziedzinie edukacji regionalnej na Kaszubach. W: K. Kossak-Główczewski: Edukacja regionalna mniejszości narodowych $i$ etnicznych. cyt. wyd., s. 27-28. 
wdrożenia treści regionalnych w przestrzeń obowiązujących przedmiotów nauczania.

„Poważniej” do problemu powrócono dopiero w 1986 roku. Wydano wówczas nowy program dla literatury (Tadeusz Lipski) i gramatyki (Edward Breza) języka polskiego wysycany treściami regionalnymi ${ }^{14}$. Wydano także wypisy z literatury kaszubskiej ze wskazówkami dla nauczycieli ${ }^{15}$. W 1987 roku zmodyfikowano istniejące programy i przygotowano projekt regionalnej tematyki kaszubsko-pomorskiej, który wpisywał się w treści ówczesnych programów nauczania. Wyodrębniły się wówczas dwa zespoły robocze. Pierwszy pod kierunkiem Edwarda Brezy pracował nad przygotowaniem programów dla szkoły podstawowej, drugi - pod przewodnictwem Jerzego Tredera - programów dla liceów ogólnokształcących ${ }^{16}$. W marcu 1987 roku rozpoczął się proces opiniowania. Na wniosek Kuratora Oświaty i Wychowania Urzędu Wojewódzkiego w Gdańsku projekty zostały skierowane do adekwatnych metodyków Oddziału Doskonalenia Nauczycieli Instytutu Kształcenia Nauczycieli w Gdańsku. Przy czym już na wstępie kurator zalecił, by: 1) materiały miały charakter suplementu pomocniczego; 2) ODN w Gdańsku miał nie tylko zaopiniować, ale i rozpowszechniać materiały dydaktyczne oraz merytorycznie przygotować nauczycieli do prowadzenia edukacji regionalnej ${ }^{17}$. Wprowadzone przez władze oświatowe zmiany w zakresie odciążenia (a właściwie okrojenia) programów kształcenia skutecznie usunęły możliwość regionalizacji programów kształcenia: dziwnym bowiem zbiegiem okoliczności odciążono program nauczania właśnie w zakresie treści regionalnych. Przyjęty i rozpowszechniony został jedynie podręcznik metodyki dla języka polskiego ${ }^{18}$.

Ten suplement dla nauczycieli języka polskiego budowany był wokół dwóch wątków: 1) wiedzy o literaturze i uwrażliwieniu oraz wprowadzeniu

14 T. Lipski, E. Breza (opracowanie): Tematyka kaszubsko-pomorska w nauczaniu języka polskiego w klasach IV-VIII szkoły podstawowej. Materiaty pomocnicze dla nauczycieli języka polskiego. Gdańsk 1987, IKN, ODN.

15 T. Lipski: Remusowi króm. Wypisy z literatury kaszubskiej dla nauczycieli języka polskiego. Gdańsk 1990, Wydawnictwo Zrzeszenie Kaszubsko-Pomorskie.

16 H. G. [Henryk Galus]: Pierwszy poradnik edukacji regionalnej. Doradë dlô szkólnëch. „Pomerania. Miesięcznik społeczno-kulturalny” 1988, nr 4 (180), s. 27.

17 Tamże.

18 Tamże, s. 27-28. T. Lipski, E. Breza (opracowanie): Tematyka kaszubsko-pomorska w nauczaniu jezyka polskiego w klasach IV-VIII szkoty podstawowej. Materiaty pomocnicze dla nauczycieli języka polskiego. cyt. wyd. 
ucznia w świat literacki, który jest mu kulturowo najbliższy, bo generowany przez region, w którym uczeń żyje; 2) nauki pisania i czytania w języku kaszubskim ${ }^{19}$. Krytyczna analiza tego suplementu prowadzi do wniosku, że władze oświatowe wyznaczyły dość wąską ideologicznie ścieżkę dla celów tzw. edukacji regionalnej w zakresie regionalizacji treści kształcenia polonistycznego. Zmiana polegała na poszerzaniu wiedzy polonistycznej o dany typ folkloru polskiego, ale w taki sposób, by nauczyciel i uczeń uzyskali przeświadczenie, że ich regionalizm jest częścią kultury polskiej, a w zasadzie lokalną odmianą kultury polskiej. A język kaszubski w tej optyce jest tym, co osiąga „status języka artystycznego”.

Ujawnia się tu swoiście skrywany konflikt w definiowaniu tego, czym jest „regionalizm”. Wprost podkreślano, że to „centrum polszczyzny”, aksjologicznie regionalizm stanowił wartością patriotyczną, ideologicznie miał być niczym innym jak ideą wychowawczą (pracy nad sobą i dla społeczeństwa) i tym, co łączy przeszłość z przyszłością ${ }^{20}$. Literackie treści kaszubskie miały pozwolić uczniowi (i nauczycielowi) wertykalnie poszerzyć własne horyzonty. Podkreślano, że regionalizm to przestrzeń rodzenia się idei i powrót do wartości domowych, ,jest [on - uzupeł. A.K.] zaczerpnięciem u źródła, jest refleksją o początku"21. W założeniu kultura regionalna stanowić miała istotny składnik kultury narodowej (polskiej), który w jej obrębie będzie zdolny do trwania i rozwoju, zachowując jednocześnie swą tożsamośćc ${ }^{22}$. I równocześnie - w obrębie tych samym treści - nie szło o to, by uczeń i nauczyciel mogli spotkać się z literaturą kaszubską jako wartością autoteliczną, ale by literatura kaszubska ${ }^{23}: 1$ ) w określony sposób umiejscowiła się w nauczaniu języka polskiego; 2) harmonijnie odnalazła się w polskości, za pomocą od-

19 T. Lipski: Kaszëbizna na lekcjach języka polskiego. Doradë dlô szkólnëch. „Pomerania. Miesięcznik społeczno-kulturalny" 1988, nr 4 (180), s. 28.

20 T. Lipski: Remusowi króm. Wypisy z literatury kaszubskiej dla nauczycieli języka polskiego. cyt. wyd.

21 T. Lipski: Czytanie w szkole. O literaturze kaszubskiej w szkole publicznej. W: W. Frankiewicz, K. Kossak-Główczewski (red.): Pedagogika Celestyna Freineta a edukacja regionalna. Gdańsk 1997, UG, s. 84.

22 H. Galus: Edukacja regionalna. Regionalizm dzisiaj. „Pomerania. Miesięcznik społeczno-kulturalny" 1989, nr 7-8, (195-196), s. 24.

23 T. Lipski: Czytanie w szkole. O literaturze kaszubskiej w szkole publicznej. W: W. Frankiewicz, K. Kossak-Główczewski (red.): Pedagogika Celestyna Freineta a edukacja regionalna. cyt. wyd., s. 82-83. 
powiedniego usytuowania „haseł regionalnych wśród zagadnień literatury ogólnopolskiej czy literatury ogólnie". W zamyśle miała być ona metodologicznie porządkowana przez teorie literatury polskiej, przez co odmawiano jej prawa do generowania samowiedzy o sobie, czyli odmawiano jej prawa do tworzenia własnej teorii siebie; 3) potwierdzała swe ukorzenienie w literaturze polskiej; 4) ujawniała i potwierdzała swe „tętno polskości”.

\section{Socjolodzy przełamują barierę „badań dla nauki”: nauka dla praktyki}

Już w 1980 roku Kaszubi „upomnieli się” nie tylko o „edukację regionalną w szkole", ale także postulowali potrzebę podjęcia badań socjologicznych, które ujawniłyby rzeczywisty stan kultury kaszubskiej i pomorskiej. Jednak dopiero w drugiej połowie lat 80. udało się podjąć kilka inicjatyw badawczych. Pierwszą był projekt: „Etniczność jako czynnik strukturalny społeczności lokalnych. Kulturowo-etniczne i strukturalne aspekty społeczności kaszubskiej”. Badania realizowane były przez zespół Komisji Socjologicznej Gdańskiego Towarzystwa Naukowego, w ramach Centralnego Programu Badań Podstawowych 09.8.4.2. Kierownikiem projektu był Marek Latoszek, uczestniczyli w nich także Brunon Synak i Henryk Galus ${ }^{24}$. Podjęte badania - a właściwie ich wyniki - uzmysłowiły nie tylko badaczom, ale i samym Kaszubom, że ich mowa zamiera. Kolejne badania z lat 1986 i 1993-1997 (prowadzone przez Brunona Synaka i badania Kazimierza Kossak-Główczewskiego) ujawniły, że zdecydowana większość rodziców widziała szkołę jako miejsce, w którym ich dzieci będą mogły nauczyć się języka kaszubskiego, nie tylko w piśmie, ale i w mowie. Sytuacja nie była więc optymistyczna: znacząco zmniejszyły się kompetencje rodziny kaszubskiej w zakresie trans-

24 H. Galus: Kulturowy pomost między pokoleniami społeczności Kaszubskiej. W: Marek Latoszek (red.): Kaszubi. Monografia socjologiczna. Socjologiczne problemy społeczności lokalnych. Tom 5. Rzeszów 1990, Wydawnictwo Towarzystwa Naukowego Organizacji i Kierowania, s. 148 i n.; H. Galus: Mechanizmy przekazu pokoleniowego między pokoleniami społeczności kaszubskich. W: H. Galus, K. Kossak-Główczewski (red.): Dziecko w zbiorowościach regionalnych. Na przykładzie Kaszub. "Zeszyty Naukowe - Pedagogika. Historia wychowania”, T. 20, Gdańsk 1992, UG; B. Synak: Język jako kryterium tożsamości kulturowo-etnicznej ludności kaszubskiej. W: H. Galus, K. Kossak-Główczewski (red.): Dziecko w zbiorowościach regionalnych. Na przyktadzie Kaszub. cyt. wyd. 
misji pokoleniowej języka kaszubskiego. Paradoksalnie najmniej otwarci byli sami nauczyciele: zdecydowana ich większość jeśli już dopuszczała obecność kaszubszczyzny w szkole, to tylko na zasadzie tzw. regionalizacji treści nauczania. Trzeba też dodać, że najmniej sceptyczni wobec obecności języka kaszubskiego w szkole okazali się sami uczniowie ${ }^{25}$.

\section{Pedagodzy we współpracy: wokół wspólnej sprawy. Konceptualizacja pedagogicznej teorii edukacji regionalnej}

20-21 maja 1988 roku z inicjatywy Instytutu Pedagogiki Uniwersytetu Gdańskiego, Komisji Oświaty Zarządu Głównego Zrzeszenia Kaszubsko-Pomorskiego oraz Krajowego Klubu Animatora Kultury Wsi „Scena Ludowa” odbywała się w Bałtyckim Uniwersytecie Ludowym w Opaleniu konferencja naukowa „Sytuacja społeczna i edukacyjna dziecka w zbiorowościach regionalnych dawniej i dziś na przykładzie Kaszub" ${ }^{26}$. Konferencja stanowiła swoisty kamień milowy w konstruowaniu interdyscyplinarnego namysłu nad kwestiami edukacji, oświaty, relacji szkoły i rodziny, relacji przeszłości (w tym tradycji) i teraźniejszości, konfrontacji wartości generowanych przez ówczesną praktykę społeczną, polityczną i edukacyjną a wartościami, które były pożądane ze względu na możliwość zachowania i rozwoju kultury kaszubskiej. Konferencja poszerzyła przestrzeń namysłu o głos pedagogów i głos pedagogiczny, który artykułowany był także przez niepedagogów. Szczególnie znaczące wydają się wypowiedzi Henryka Galusa, Brunona Synaka i Jana

25 Tamże. B. Synak: Kaszubska tożsamość: ciagłość i zmiana. Studium socjologiczne. Gdańsk 1998, UG, s. 176-230; M. Latoszek: Wokót funkcji przekazywania języka przez instytucje społeczne. W: E. Breza (red.): Problem statusu jezykowego kaszubszczyzny. Gdańsk 1992, Wydawnictwo: Zrzeszenie Kaszubsko-Pomorskie; K. Kossak-Główczewski: Kaszubi o własnych języku w szkole (Interpretacja wyników badań w świetle koncepcji reprodukcji P. Bourdieu). W: E. Rodziewicz, M. Szczepska-Pustkowska (red.): Od pedagogiki ku pedagogii. Toruń 1993, Wydawnictwo Edytor. K. Kossak-Główczewski: Przeszkody i nadzieja zaistnienia edukacji regionalnej a transformacja spoteczna. W: K. Kossak-Główczewski (red.): Jana Drzeżdżona nie dokończony tryptyk społeczny a edukacja regionalna. Gdańsk 1995,UG.

26 J. Zbyrzyca [S. Pestka]: Edukacja na dwa fronty. „Pomerania. Miesięcznik społeczno-kulturalny" 1988, nr 9 (185), s. 17-19; H. Galus, K. Kossak-Główczewski (red.): Dziecko w zbiorowościach regionalnych. Na przykładzie Kaszub. „Zeszyty Naukowe Pedagogika. Historia wychowania", T. 20, Gdańsk 1992, UG. 
Drzeżdżona ${ }^{27}$. Po raz pierwszy w tak dużej formacji interlokutorzy rozmawiali o kondycji dziecka socjalizowanego w obrębie kultury mniejszościowej, którego edukacja formalna dzieje się w obrębie kultury większościowej. Dyskusja była swoistym podsumowaniem stanu wiedzy i refleksji wobec wyzwać edukacyjnych. Można zaryzykować tezę, że Kaszubi mieli już dość argumentów naukowych, kulturowo-społecznych i politycznych, by świadomie odejść od tzw. regionalizacji nauczania i zmierzać ku własnej - w miarę dojrzałej - koncepcji edukacji kaszubskiej. Jest to też moment, w którym podjęta zostaje próba konstruowania myślenia pedagogicznego wobec regionalizacji nauczania i edukacji regionalnej jako dwóch odmiennych i jednocześnie przeciwstawnych typów działań (i racjonalności) edukacyjnych.

W trakcie debaty Kazimierz Kossak-Główczewski dokonuje krytycznego namysłu nad kategorią „regionalności”. Wyraźnie wyodrębnia „region” jako przestrzeń społeczno-kulturową i przeciwstawia jej „regionalność” jako myślenie o regionie. „Regionalność” nie jest jednak nową kategorią w kaszubskim namyśle społecznym nad kwestiami kultury, ale w myśleniu Kazimierza Kossak-Główczewskiego została ona wykorzystana na sposób metodologiczny. Jest więc „regionalność” myśleniem o regionie, które autor silnie nasyca wartościami antropologicznymi i kulturowymi ${ }^{28}$. „Regionalność” to także teoretyczna konceptualizacja procesów zachodzących w regionie i otwarcie nowego pola problemowego, które ułatwia „dostrzeganie problemów nieobecnych w racjonalności instrumentalnej”29. Takie metodologiczne zagospodarowanie „regionalności” pozwoliło K. Kossak-Główczewskiemu na skonstruowanie koncepcji edukacji regionalnej jako myślenia emancypacyjno-hermeneutycznego o edukacji ${ }^{30} \mathrm{i}$ regionalizacji nauczania jako technologii

27 J. Zbyrzyca [S. Pestka]: Edukacja na dwa fronty. „Pomerania. Miesięcznik społeczno-kulturalny" 1988, nr 9 (185), s. 17-19.

28 K. Kossak-Główczewski: Edukacja a wartości regionalne i wartości społeczeństwa globalnego. Zarys problematyki. W: H. Galus, K. Kossak-Główczewski (red.): Dziecko w zbiorowościach regionalnych. Na przyktadzie Kaszub. cyt. wyd.

29 K. Kossak-Główczewski: Przedzałożenia edukacji wielokulturowej, międzykulturowej i regionalnej a "prywatne i regionalne ojczyzny" - szkic do problemu edukacji kaszubskiej. W: K. Kossak-Główczewski: Szkice z edukacji regionalnej. Europa. Regiony. Kaszubi. Rumia - Głodnica 1996, Wydawnictwo Rumina, s. 49.

30 K. Kossak-Główczewski: Niezależna edukacja regionalna. „Pomerania. Miesięcznik społeczno-kulturalny” 1990, nr 9 (209), s. 10-11. K. Kossak-Główczewski: Regionalizacja nauczania a nauczanie regionalne. „Pomerania. Miesięcznik społeczno-kulturalny" 1990, nr 10 (210), s. 18. K. Kossak-Główczewski: Regionaliza- 
adaptacyjnej do systemu politycznego kultury dominującej/opresyjnej, która prowadzi do degradacji kultury etnicznej/mniejszościowej. Konfrontacyjne ustawienie kultur w konsekwencji degraduje i kulturę mniejszościową, jak i kulturę większościową. Ta druga pozbawiona zostaje bowiem treści różnicujących i pobudzających do kulturowego wzrostu ${ }^{31}$.

„Regionalizację nauczania - pisze K. Kossak-Główczewski - cechuje [...] nasycanie istniejących programów nauczania treściami regionalnymi tak, że dostosowują się one do wewnętrznej logiki istniejących, centralnie nadawanych treści kształcenia. Regionalizacja nauczania legitymizuje zastane struktury władzy przez fakt współpracy (kolaborację) z nimi”32. Idzie więc o to, by tak manipulować wartościami regionalnymi, by w konsekwencji zwiększyć efektywność formalnych programów kształcenia i poddać ucznia procesowi nadkontroli. Ważne są bowiem cele odgórnie założone i zaakceptowane przez władze oświatowe ${ }^{33}$, zaś „nauczyciele-regionaliści”, wpisani w ten typ edukacji, (nie)świadomie stają się „agentami władzy”34. Treści należy zestawić w taki sposób, by się one wzajemnie uzupełniały, ale tylko w optyce celów kultury dominującej, a właściwie w przestrzeni jej ideologii. Zabieg ten czyni konflikt submisyjne-dominujące niewidocznym. Regionalizacja jest więc

cja nauczania a edukacja regionalna jako odmiany racjonalności emancypacyjnej. W: W. Frankiewicz, K. Kossak-Główczewski (red.): Pedagogika Celestyna Freineta a edukacja regionalna. cyt. wyd., s. 110.

31 K. Kossak-Główczewski: W poszukiwaniu źródeł realizacji poprzez edukacje regionalna a pedagogikę Freineta. W: W. Frankiewicz, K. Kossak-Główczewski (red.): Pedagogika Celestyna Freineta a edukacja regionalna. cyt. wyd., s. 18-22. K. Kossak-Główczewski: Regionalizacja nauczania a edukacja regionalna jako odmiany racjonalności emancypacyjnej. W: W. Frankiewicz, K. Kossak-Główczewski (red.): Pedagogika Celestyna Freineta a edukacja regionalna. cyt. wyd., s. 112.

32 K. Kossak-Główczewski: W poszukiwaniu źródet realizacji poprzez edukacje regionalna a pedagogikę Freineta. W: W. Frankiewicz, K. Kossak-Główczewski (red.): Pedagogika Celestyna Freineta a edukacja regionalna. cyt. wyd., s. 21.

33 K. Kossak-Główczewski: Dwie pedagogiki i ich społeczne konsekwencje. W: J. Rutkowiak (red.): Zagadnienia celów edukacyjnych. Materiaty do nauczania pedagogiki. Gdańsk 1987, Wydawnictwo Uniwersytetu Gdańskiego, s. 62-63. K. Kossak-Główczewski: Niezależna edukacja regionalna. „Pomerania. Miesięcznik społeczno-kulturalny" 1990, nr 9 (209), s. 8-9.

34 K. Kossak-Główczewski: W poszukiwaniu źródeł realizacji poprzez edukacje regionalna a pedagogikę Freineta. W: W. Frankiewicz, K. Kossak-Główczewski (red.): Pedagogika Celestyna Freineta a edukacja regionalna. cyt. wyd., s. 17. 
niczym innym jak narzędziem legitymizacji istniejących dominujących ideologii i programów edukacyjnych. Jest to zabieg, który „powinien pojednać” interesy kulturowe grupy mniejszościowej z interesami kulturowymi grupy dominującej3.

„Edukacja regionalna - jak podkreśla K. Kossak-Główczewski - umożliwia powrót do domu, do źródeł życia każdego człowieka, do źródeł jego etyki i jego języka, a więc do źródeł kultury domowej, lokalnej, regionalnej, narodowej i ogólnoludzkiej. U podłoża tego stwierdzenia tkwi ważkie teoretyczne i społeczne założenie, iż najbliższe otoczenie człowieka, nazywane przez S[tanisława - uzupeł. A.K.] Ossowskiego prywatną ojczyzną, jest jednocześnie światem ogólnoludzkim (globalnym), tzn. światem ludzkim w całej jego rozciągłości”"36. Szczególność edukacji regionalnej polega na tym, że jest ona "tworzona przez zainteresowanych" 37 , a więc to sami Kaszubi decydują o tym, jakie wartości i treści kultury regionalnej zostaną wprowadzone w proces edukacji, której celem jest pokoleniowy przekaz wartości kulturowych. Wartości i treści regionalne mają jednocześnie charakter ogólnoludzki, gdyż wywodzą się ze świata całościowego i ludzkiego ${ }^{38}$. W swej teorii edukacji regionalnej K. Kossak-Główczewski przyjmuje tezę - nienową w myśli pedagogicznej - że „edukacja jest kulturą", a jednym z jej źródeł jest etnicznośćc ${ }^{39}$. Założenie to stanowi jeden z filarów omawianej teorii i uzmysławia,

35 K. Kossak-Główczewski: Regionalizacja nauczania a nauczanie regionalne. „Pomerania. Miesięcznik społeczno-kulturalny” 1990, nr 10 (210), s. 18-19; K. Kossak-Główczewski: Regionalizacja nauczania a edukacja regionalna jako odmiany racjonalności emancypacyjnej. W: W. Frankiewicz, K. Kossak-Główczewski (red.): Pedagogika Celestyna Freineta a edukacja regionalna. cyt. wyd., s. 109-110.

36 K. Kossak-Główczewski: W poszukiwaniu źródet realizacji poprzez edukację regionalna a pedagogikę Freineta. W: W. Frankiewicz, K. Kossak-Główczewski (red.): Pedagogika Celestyna Freineta a edukacja regionalna. cyt. wyd., s. 18. K. Kossak-Główczewski: Regionalizacja nauczania a nauczanie regionalne. „Pomerania. Miesięcznik społeczno-kulturalny" 1990, nr 10 (210), s. 19-20.

37 K. Kossak-Główczewski: Niezależna edukacja regionalna. „Pomerania. Miesięcznik społeczno-kulturalny" 1990, nr 9 (209), s. 9. Por. także: Wypowiedź Edwarda Brezy: E. Szcześniak, E. Breza i J. Trederem: Wszystkie barwy stów. „Pomerania. Miesięcznik społeczno-kulturalny" 1983, nr 6 (122), s. 1.

38 K. Kossak-Główczewski: W poszukiwaniu źródet realizacji poprzez edukację regionalnq a pedagogikę Freineta. W: Wanda Frankiewicz, Kazimierz Kossak-Główczewski (red.), Pedagogika Celestyna Freineta a edukacja regionalna. cyt. wyd., s. 20-21.

39 K. Kossak-Główczewski: Niezależna edukacja regionalna. „Pomerania. Miesięcz- 
że edukacja regionalna może być „metodą” przeciwdziałania tendencjom kolonizacyjnym i może gwarantować zachowanie oraz rozwój tożsamości małej grupy kulturowej. Może też ona być „narzędziem” wzbudzania separatyzmów i „kulturowych zamknięć”40.

\section{Edukacja kaszubska: aspekt metodyczny i pedagogiczny (teoretyczny). W stronę konkluzji}

Możliwość przyglądania się dziejom myśli i praktyki z innego miejsca i czasu daje badaczowi możliwości rozpoznania mechanizmów, jakie legły u podstaw kontrowania teorii, tu: edukacji kaszubskiej, jako edukacji regionalnej i pedagogicznej teorii edukacji regionalnej.

Kaszubska edukacja regionalna jawi się jako metodyka działania edukacyjnego. Takie rozpoznanie staje się bardziej wyraźne, kiedy ten artykuł zestawi się z tekstem „Edukacja języka i kultury kaszubskiej na terenie Kaszub. Wybrane aspekty”" ${ }^{41}$, który napisałam wspólnie z Kazimierzem Kossak-Głów-

nik społeczno-kulturalny" 1990, nr 9 (209), s. 9. Patrz: S. Kot: Wychowanie i historyja wychowania. W: S. Kot: Historja wychowania. Zarys podręcznikowy, T. 1: Od starożytnej Grecji do polowy w. XVIII. Lwów 1934, Państwowe Wydawnictwo Książek Szkolnych; S. Kot: Przedmiot i zakres historii wychowania. W: S. Kot: Zarys dziejów wychowania jako funkcji społecznej. Przedruk z „Encyklopedii Wychowania”. Warszawa 1947, „Nasza Księgarnia"; T. Szkudlarek: Wstęp. W: T. Szkudlarek (red.): Różnica, tożsamość, edukacja. Szkice z pogranicza. Kraków 1995, Oficyna Wydawnicza „Impuls”.

40 K. Kossak-Główczewski: Regionalizacja nauczania a nauczanie regionalne. „Pomerania. Miesięcznik społeczno-kulturalny” 1990, nr 10 (210), s. 20; K. Kossak-Główczewski: W poszukiwaniu źródet realizacji poprzez edukację regionalnq a pedagogikę Freineta. W: W. Frankiewicz, K. Kossak-Główczewski (red.): Pedagogika Celestyna Freineta a edukacja regionalna. cyt. wyd., s. 21; K. Kossak-Główczewski: Regionalizacja nauczania a edukacja regionalna jako odmiany racjonalności emancypacyjnej. W: W. Frankiewicz, K. Kossak-Główczewski (red.): Pedagogika Celestyna Freineta a edukacja regionalna. cyt. wyd., s. 110; K. Kossak-Główczewski: Pytania i niektóre aspekty niezależnej edukacji regionalnej. W: B. Śliwerski (red.): Edukacja alternatywna. Dylematy teorii i praktyki. Materiaty Międzynarodowej Konferencji w Dobieszowie k/Łodzi w dniach 15-17 października 1992 r. Kraków 1992, Oficyna Wydawnicza „Impuls”, s. 153.

41 A. Kożyczkowska, K. Kossak-Główczewski: Edukacja języka i kultury kaszubskiej na terenie Kaszub. Wybrane aspekty. W: T. Lewowicki, J. Nikitorowicz, A. Szczurek-Boruta (red.): Szkoty dla mniejszości narodowych i spoteczności kaszubskiej w Polsce - stan, problemy, perspektywy. Warszawa - Cieszyn - Białystok 2013, Wyższa 
czewskim, a który opisuje działania edukacyjne po roku 1991. Ale ujęcie metodyczne edukacji regionalnej nie pozbawia jej ani metodologii, ani potrzeby poszukiwania teorii wyjaśniających, ani też możliwości konstruowania własnych teorii edukacyjnych. W tak konstruowanej metodycznej teorii edukacji istotne okazują się trzy momenty, na które musi być ona ciągle wrażliwa: 1) diagnoza stanu aktualnego, czyli ciągle rozpoznawanie tego, jak jest; 2) diagnoza tego, jak być powinno; 3 ) odpowiedź na pytanie: jak zmienić to, co jest, w to, co być powinno? Jak osiągnąć stan idealny?

Diagnoza stanu aktualnego z konieczności powinna zakładać zmienność rzeczywistości społeczno-kulturowej jako świata życia ludzkiego. To stąd Kaszubi dopominali się badań socjologicznych, które dałyby im odpowiedź na to pytanie. Diagnoza tego, jak być powinno, wynika z faktu, że każde życie wspólnotowe determinowane jest jakąś samowiedzą o tym, jaki powinien być jego stan idealny. Dla Kaszubów ważne było i jest, by kultura i język kaszubski były żywe, a wspólnota kaszubska rządziła się ideami demokracji i zasadą bycia gospodarzem u siebie, przy jednocześnie zachowanej autonomii kulturowej. Nie da się ukryć, że to stan utopii społecznej i politycznej, ale każda społeczność musi „jakoś” wiedzieć, jak żyć i w jakim kierunku to życie kierować. Kaszubi jak każda inna społeczność potrzebują więc wizjonerów. „Metodą” uzyskania „tego, jak być powinno” jest edukacja, tu: edukacja kaszubska. Tylko ona mogła i może zapewnić ciągłość kultury i języka kaszubskiego, co szczególnie potwierdziły pierwsze badania socjologiczne. Tak konstruowana metodyczna teoria edukacji regionalnej budowana jest na dwóch przesłankach, które jednocześnie urealnia w praktyce $\left.{ }^{42}: 1\right)$ jest praktyką społeczną - umożliwia bowiem poznanie określonej rzeczywistości społecznej, dzięki temu, że analizuje i syntezuje wiedzę społeczną; 2) jest praktyką polityczną - bo przekształca istniejącą rzeczywistość społeczną, przy okazji zmienia też charakter instytucji, które tę rzeczywistość tworzą, czyli rodzinę, szkołę, Kościół, związki i stowarzyszenia itp.

Teoria edukacyjna - by mogła się rozwijać i zmieniać tak, by ciągle odpowiadać potrzebom społeczności, która ją wygenerowała - może potrzebować pedagogicznego namysłu nad sobą (choć może z tego zrezygnować, czego

Szkoła Pedagogiczna ZNP, Uniwersytet Śląski w Katowicach, Uniwersytet w Białymstoku, Stowarzyszenie Wspierania Edukacji Międzykulturowej.

42 Por. J. Habermas: Niektóre trudności próby zwiazania teorii z praktyka. Wprowadzenie do nowego wydania, W: J. Habermas: Teoria i praktyka. Wybór pism. Warszawa 1993, PIW, s. 24-26. 
konsekwencje łatwo przewidzieć). Konfrontując wytworzoną teorię edukacji kaszubskiej, którą rozpoznałam jako metodyczną teorię edukacji regionalnej, z teorią zrekonstruowaną przez Kazimierza Kossak-Główczewskiego, rozpoznać można logicznie po sobie następujące etapy działań. Zaczynając od końca, mamy: pedagogiczna teoria edukacji regionalnej $\leftarrow$ metodyczna teoria edukacji regionalnej $\leftarrow$ światopogląd, wiedza i doświadczenie wspólnotowe $\leftarrow$ światopogląd, wiedza i doświadczenie jednostkowe.

Pedagogiczna teoria edukacji regionalnej stanowi logiczną konsekwencję metodycznej teorii edukacji regionalnej, która będąc efektem praktyki społecznej, jest niczym innym jak warunkiem koniecznym przetrwania danej wspólnoty kulturowej. W pedagogicznej teorii edukacji ważne są dwie sprawy: kto mówi i w czyim imieniu. Nie jest oczywiście istotne nazwisko, ale istotne było to, że mówi Kaszuba-pedagog-naukowiec, który rangą uniwersyteckich dyplomów potwierdza nie tylko ważność, ale i prawdziwość tego, o czym mówi i w czyim imieniu. A mówi(ł) w imieniu wspólnoty i mówi(ł) o tym, co ważne i prawdziwe dla Kaszubów. Konstruowana teoria musiała zatem odzwierciedlać ideologie wspólnoty i jej (samo)wiedzę oraz wspólnotowe doświadczenia (np. doświadczenie wydziedziczania z rodzimych dóbr kulturowych, stąd „powrót do domu, do źródeł życia”). Nie idzie więc o tworzenie nowych kategorii i wypełnianie ich nowymi treściami, ale idzie o to, by teoria odzwierciedlała i wyjaśniała świat praktyki. Dlatego też praktyczne pojęcia wytwarzane przez wspólnotę w praktyce życia codziennego zostały w tworzonej teorii pedagogicznej konwertowane w pojęcia pedagogiczne, antropologiczne, filozoficzne, naukowe itp. Podobnie jak w przypadku metodycznej teorii rozpoznać można dwie podstawy i dwa cele: społeczny i polityczny. Pierwszy stanowi analizę i krytyczną interpretację praktyki społecznej. Drugi stawia sobie za cel zmianę instytucji społecznych, po to, by zmienić świat społeczny, który te instytucje wytworzył.

\section{Bibliografia}

Bądkowski L.: My, literaci, żyjemy w środku narodu. „Pomerania. Zarząd Główny Zrzeszenia Kaszubsko-Pomorskiego" 1981, nr 3 (110).

Galus H.: Edukacja regionalna. Regionalizm dzisiaj. „Pomerania. Miesięcznik społeczno-kulturalny" 1989, nr 7-8, (195-196).

Galus H.: Kulturowy pomost między pokoleniami społeczności Kaszubskiej. 
W: M. Latoszek (red.): Kaszubi. Monografia socjologiczna. Socjologiczne problemy społeczności lokalnych. T. 5. Rzeszów 1990, Wydawnictwo Towarzystwa Naukowego Organizacji i Kierowania.

Galus H.: Mechanizmy przekazu pokoleniowego między pokoleniami społeczności kaszubskich. W: H. Galus, K. Kossak-Główczewski (red.): Dziecko w zbiorowościach regionalnych. Na przyktadzie Kaszub. „Zeszyty Naukowe - Pedagogika. Historia wychowania”, T. 20, Gdańsk 1992, UG.

Galus H.: Szkoła i region. „Pomerania. Miesięcznik społeczno-kulturalny” 1986, nr 5 (157).

G.H. [Galus Henryk]: Pierwszy poradnik edukacji regionalnej. Doradë dlô szkólnëch. „Pomerania. Miesięcznik społeczno-kulturalny” 1988, nr 4 (180).

Habermas J.: Niektóre trudności próby zwiąania teorii z praktyka. Wprowadzenie do nowego wydania. W: J. Habermas: Teoria i praktyka. Wybór pism. Warszawa 1993, PIW.

Kossak-Główczewski K.: Dwie pedagogiki i ich społeczne konsekwencje. W: J. Rutkowiak (red.): Zagadnienia celów edukacyjnych. Materiaty do nauczania pedagogiki. Gdańsk 1987, UG.

Kossak-Główczewski K.: Edukacja a wartości regionalne i wartości społeczeństwa globalnego. Zarys problematyki. W: H. Galus, K. Kossak-Główczewski (red.): Dziecko w zbiorowościach regionalnych. Na przykładzie Kaszub. „Zeszyty Naukowe - Pedagogika. Historia wychowania”, T. 20. Gdańsk 1992, UG.

Kossak-Główczewski K.: Kaszubi o własnym języku w szkole (Interpretacja wyników badań w świetle koncepcji reprodukcji P. Bourdieu). W: E. Rodziewicz, M. Szczepska-Pustkowska (red.): Od pedagogiki ku pedagogii. Torun 1993, „Edytor”.

Kossak-Główczewski K.: Niezależna edukacja regionalna. „Pomerania. Miesięcznik społeczno-kulturalny" 1990, nr 9 (209).

Kossak-Główczewski K.: Przedzałożenia edukacji wielokulturowej, międzykulturowej i regionalnej a "prywatne i regionalne ojczyzny” - szkic do problemu edukacji kaszubskiej. W: K. Kossak-Główczewski: Szkice z edukacji regionalnej. Europa. Regiony. Kaszubi. Rumia - Głodnica 1996, Wydawnictwo „Rumina”.

Kossak-Główczewski K.: Przeszkody i nadzieja zaistnienia edukacji regionalnej a transformacja społeczna. W: K. Kossak-Główczewski (red.): Jana Drzeżdżna nie dokończony tryptyk społeczny a edukacja regionalna. Gdańsk 1995, UG. 
Kossak-Główczewski K.: Pytania i niektóre aspekty niezależnej edukacji regionalnej. W: B. Śliwerski (red.): Edukacja alternatywna. Dylematy teorii i praktyki. Materiaty Międzynarodowej Konferencji w Dobieszowie k/Łodzi w dniach 15-17 października 1992 r. Kraków 1992, Oficyna Wydawnicza „Impuls”.

Kossak-Główczewski K.: Regionalizacja nauczania a edukacja regionalna jako odmiany racjonalności emancypacyjnej. W: W. Frankiewicz, K. Kossak-Główczewski (red.): Pedagogika Celestyna Freineta a edukacja regionalna. Gdańsk 1997, UG.

Kossak-Główczewski K.: Regionalizacja nauczania a nauczanie regionalne. „Pomerania. Miesięcznik społeczno-kulturalny” 1990, nr 10 (210).

Kossak-Główczewski K.: W poszukiwaniu źródet realizacji poprzez edukacje regionalnq a pedagogike Freineta. W: W. Frankiewicz, K. Kossak-Główczewski (red.): Pedagogika Celestyna Freineta a edukacja regionalna. Gdańsk 1997, UG.

Kot S.: Przedmiot i zakres historii wychowania. W: S. Kot: Zarys dziejów wychowania jako funkcji społecznej. Przedruk z „Encyklopedii Wychowania”. Warszawa 1947, Instytut Wydawniczy „Nasza Księgarnia”.

Kot S.: Wychowanie i historyja wychowania, W: S. Kot: Historja wychowania. Zarys podręcznikowy, Tom 1: Od starożytnej Grecji do polowy w. XVIII. Lwów 1934, Państwowe Wydawnictwo Książek Szkolnych.

Kożyczkowska A., Kossak-Główczewski K.: Edukacja języka i kultury kaszubskiej na terenie Kaszub. Wybrane aspekty. W: T. Lewowicki, J. Nikitorowicz, A. Szczurek-Boruta (red.): Szkoty dla mniejszości narodowych i spoteczności kaszubskiej w Polsce - stan, problemy, perspektywy. Warszawa - Cieszyn - Białystok 2013, Wydawca Wyższa Szkoła Pedagogiczna ZNP, Uniwersytet Śląski w Katowicach, Uniwersytet w Białymstoku, Stowarzyszenie Wspierania Edukacji Międzykulturowej.

Kożyczkowska K., „Aktywne uczestnictwo” jako zasada obywatelskości i warunek demokratyzacji życia w regionie i państwie. Casus kaszubsko-pomorskiego ruchu regionalnego. Maszynopis złożony do druku.

Latoszek M.: Pomorze: odkrywanie tożsamości w procesie dtugiego trwania. W: W. Świątkiewicz (red.): Regiony i regionalizmy w Polsce Wspótczesnej. Katowice 1998, UŚ, Śląskie Towarzystwo Socjologiczne.

Latoszek M.: Pomorze: zagadnienia etniczno-regionalne, Gdańsk 1996, Gdańskie Towarzystwo Naukowe, Akademia Medyczna w Gdańsku.

Latoszek M.: Wokót funkcji przekazywania języka przez instytucje społeczne. 
W: E. Breza (red.): Problem statusu językowego kaszubszczyzny. Gdańsk 1992, Wydawnictwo: Zrzeszenie Kaszubsko-Pomorskie.

Lipski T.: Czytanie w szkole. O literaturze kaszubskiej w szkole publicznej. W: W. Frankiewicz, K. Kossak-Główczewski (red.): Pedagogika Celestyna Freineta a edukacja regionalna. Gdańsk 1997, UG.

Lipski T.: Kaszëbizna na lekcjach języka polskiego. Doradë dlô szkólnëch. „Pomerania. Miesięcznik społeczno-kulturalny" 1988, nr 4 (180).

Lipski T.: Remusowi króm. Wypisy z literatury kaszubskiej dla nauczycieli języka polskiego. Gdańsk 1990, Wydawnictwo Zrzeszenie Kaszubsko-Pomorskie.

Lipski T., Breza E. (opracowanie): Tematyka kaszubsko-pomorska w nauczaniu języka polskiego w klasach IV-VIII szkoty podstawowej. Materiaty pomocnicze dla nauczycieli języka polskiego. Gdańsk 1987, IKN, ODN.

Materiaty do dyskusji na temat regionalizacji nauczania. XI Spotkania Twórców Literatury Kaszubsko-Pomorskiej, Wdzydze, 9-10 X 1981.

Obracht-Prondzyński C.: Kaszubi: między dyskryminacją a regionalnq podmiotowościa. Gdańsk 2002, Wydawnictwo Instytutu Kaszubskiego.

Samp J.: Na których czekamy. „Pomerania. Miesięcznik społeczno-kulturalny” 1983, nr 5 (121).

Samp J.: Zanim staniesz się niemy w mowie ojców (dokończenie). „Pomerania. Miesięcznik społeczno-kulturalny" 1984, nr 8 (136)

Samp J.: Zanim staniesz się niemy w mowie ojców. „Pomerania. Miesięcznik społeczno-kulturalny" 1984, nr 7 (135).

Sochacki O.: Obraz Kaszubów w opinii publicznej. „Pomerania. Miesięcznik społeczno-kulturalny" 1987, nr 10.

Synak B.: Język jako kryterium tożsamości kulturowo-etnicznej ludności kaszubskiej. W: H. Galus, K. Kossak-Główczewski (red.): Dziecko w zbiorowościach regionalnych. Na przykładzie Kaszub. „Zeszyty Naukowe - Pedagogika. Historia wychowania", T. 20, Gdańsk 1992, UG.

Synak B.: Kaszubska tożsamość: ciagtość i zmiana. Studium socjologiczne. Gdańsk 1998, UG.

Szcześniak E., Breza E., Treder J.: Wszystkie barwy słów. „Pomerania. Miesięcznik społeczno-kulturalny" 1983, nr 6 (122).

Szczęsny F.: Kurs na młodzież. „Pomerania. Zarząd Główny Zrzeszenia Kaszubsko-Pomorskiego" 1980, nr 1 (96).

Szkudlarek T.: Wstęp. W: T. Szkudlarek (red.): Różnica, tożsamość, edukacja. Szkice z pogranicza... Praca zbiorowa. Kraków 1995, Oficyna Wydawnicza „Impuls”. 
Talewski Z.: Do kolegi Lecha Bądkowskiego stów kilka. „Pomerania. Zarząd Główny Zrzeszenia Kaszubsko-Pomorskiego" 1981, nr 8 (115).

Treder J.: Niektóre inicjatywy w dziedzinie edukacji regionalnej na Kaszubach. W: K. Kossak-Główczewski, Edukacja regionalna mniejszości narodowych i etnicznych. Gdańsk 1999, UG.

Trojanowska I., Czermińska M.: Pisarze o nauczaniu w szkole. „Pomerania. Zarząd Główny Zrzeszenia Kaszubsko-Pomorskiego” 1981, nr 8 (115).

Trojanowska I.: Wypowiedź w ramach Zjazdu. „Pomerania. Zarząd Główny Zrzeszenia Kaszubsko-Pomorskiego" 1981, nr 2 (109).

Uchwała Walnego Zjazdu Delegatów Zrzeszenia Kaszubsko-Pomorskiego. Gdańsk, 14 grudzień 1980 r. „Pomerania. Zarząd Główny Zrzeszenia Kaszubsko-Pomorskiego" 1981, nr 2 (109).

Zbyrzyca J. [S. Pestka]: Edukacja na dwa fronty. „Pomerania. Miesięcznik społeczno-kulturalny" 1988, nr 9 (185).

\section{Kashubian education: how educational practice "sowed" and consolidated the pedagogical thought. An invitation to think over the theory of practice}

\section{Summary}

The article describes a part of social practice in which the Kashubian community in Polish People's Republic and in times of transformational breakthrough took some actions. They strived to protect the rights to preserve their language and culture, as well as cross-generation culture transmission. In particular, they demanded the right to Kashubian education at school. The article also describes some aspects of social and educational ideas which appeared in the Kashubian space. Finally the article describes the theory of regional education of Kazimierz Kossak-Główczewski.

Key words: Kashubian education, regional education, methodical theory of regional education, pedagogical theory of regional education 